\title{
Towards a generalised physicochemical modelling framework
}

\author{
D. J. Batstone
}

Published online: 10 April 2009

(C) Springer Science+Business Media B.V. 2009

At a number of recent workshops, the topic of phosphorous modelling has been raised as a key issue. This is particularly with respect to anaerobic digester modelling, but also for chemical phosphorous removal. Phosphorous precipitation and dissolution are physicochemical reactions, parts of a system which we currently have limited capacity to properly simulate. Physicochemical reactions are those which occur without a biological mediator, and are strongly related to the $\mathrm{pH}$ system. They include gas-liquid transfer, acid-base reactions, metal-ligand ion precipitation, and a variety of liquid phase complexing reactions.

Physicochemical reactions are highly important for research and application in industrial biotechnology, wastewater treatment, and drinking water. Examples where physicochemical reactions are critical to operation include: (a) use of aluminium sulphate, and ferric/ferrous chloride for phosphorous removal in almost all phosphorous removal wastewater systems; (b) use of the same ions as coagulants in drinking water treatment; (c) gas-liquid transfer for aeration; (d) generation of odours and methane in sewer systems; (e) the $\mathrm{pH}$ drop caused by nitrification, and the potential impact of low $\mathrm{pH}$ on biological processes;

D. J. Batstone $(\bowtie)$

Advanced Water Management Centre,

The University of Queensland, Brisbane,

QLD 4072, Australia

e-mail: damienb@awmc.uq.edu.au (f) the impact of many inhibitors (e.g. nitrous acid, hydrogen sulphide, ammonia) is primarily related to either the acid or base form, and is hence heavily impacted by $\mathrm{pH}$; (g) anaerobic digester souring, where a low $\mathrm{pH}$ causes inhibition of acid consumers in a reinforcing feedback loop and (h) detection of weak acids and bases by their buffering capacity around their characteristic equilibrium constant $\left(K_{\mathrm{a}}\right)$.

The impacts of the physicochemical system is often underestimated. For example, aeration processes are heavily impacted by the acidity and ionic strength of the target solution. Naturally, given the importance of the above processes, there has been considerable research conducted into characterising physicochemical systems. However, often these have been very much orientated towards the system being identified, rather than using a more generic approach. As examples, methods to represent the $\mathrm{pH}$ and buffering systems have included the alkalinity concept in activated sludge models (Henze et al. 2000), a more sophisticated variant of this that explicitly calculated the pH (Siegrist et al. 2002), the algebraic approach of the ADM1 (Batstone et al. 2002), and the differential approach as developed at the University of Cape Town (Musvoto et al. 2000), which also included the impact of ion activity.

Even interactions between simple models such as the ASM1, and ADM1 require complex interfaces to make charge and pH consistent (Nopens et al. 2009). More challenging systems such as iron and alum precipitation and coagulation, which are complicated 
by multiple reactive species, competitive processes, as well as ion activity and pairing use mainly empirical models (Takacs et al. 2006).

At low concentrations, in simple systems, modelling of physicochemical systems is relatively simple. It involves implementation and solution of a limited number of weak acid species, as well as solution of the charge balance, either as part of an algebraic loop, or in a set of fast differential equations. At slightly higher strength (e.g. domestic wastewater), the system can be adequately corrected using ionic strength relationships (Musvoto et al. 2000). At significantly elevated strengths (e.g. anaerobic digesters, landfills), ion pairing and polymerisation have a strong impact (Tait et al. 2009), in this example, causing a fourfold increase in the apparent solubility of calcium sulphate.

Emerging processes such as bio-electrochemical systems (Picioreanu et al. 2007), and nutrient recovery by crystallisation (Kim et al. 2007) have complicated the issue. Modelling these processes requires re-assessment of existing techniques, which due to system non-linearity are even more impacted by nonideal solution behaviour.

The predominance of physicochemical processes provides strong motivation to properly characterise them. This would be enhanced by development of a generalised framework for modelling physicochemical systems. The challenges in this task include:-

- Accurate equilibrium modelling. This should offer a simple, expandable framework that can also encompass complex interactions at higher wastewater strengths. This has possibly been best addressed so far, mainly in the geochemical context by software packages such as PHREEQC (Parkhurst and Appelo 1999), though these need to be rationalised to the water and wastewater context.

- Classification, evaluation, and characterisation of kinetic relationships. While acid-base reactions are generally fast, the process of crystallisation, coagulation, and flocculation is extremely complicated. While there has been excellent work done on specific compounds, a generalised classification and modelling approach needs to be developed.

- Implementation and expansion to other applications. A great example is application to bioelectrochemical systems, where the standard charge balance approach can be applied to the electrochemical system, by addition of another implicit algebraic equation (Picioreanu et al. 2007).

While these are significant challenges, the opportunities are great, as almost every water or wastewater process is strongly influenced by these reactions. Proper characterisation would allow process wide improvements, substantial cost and resource use reductions, and allow better recovery of the valuable components in wastewater and other residual streams.

\section{References}

Batstone DJ, Keller J, Angelidaki I, Kalyuzhnyi SV, Pavlostathis SG, Rozzi A, Sanders WTM, Siegrist H, Vavilin VA (2002) Anaerobic digestion model no. 1 (ADM1), IWA task group for mathematical modelling of anaerobic digestion processes. IWA Publishing, London

Henze M, Gujer W, Mino T, van Loosdrecht M (2000) Activated sludge models ASM1, ASM2, ASM2d, and ASM3. IWA Scientific and Technical Report, London

Kim D, Ryu HD, Kim MS, Kim J, Lee SI (2007) Enhancing struvite precipitation potential for ammonia nitrogen removal in municipal landfill leachate. J Hazard Mater 146(1-2):81-85. doi:10.1016/j.jhazmat.2006.11.054

Musvoto E, Wentzel M, Loewenthal R, Ekama G (2000) Integrated chemical-physical processes modelling-I. Development of a kinetic-based model for mixed weak acid/base systems. Water Res 34(6):1857-1867. doi: 10.1016/S0043-1354(99)00334-6

Nopens I, Batstone DJ, Copp JB, Jeppsson U, Volcke E, Alex J, Vanrolleghem PA (2009) An ASM/ADM model interface for dynamic plant-wide simulation. Water Res 43:1913-1923. doi:10.1016/j.watres.2009.01.012

Parkhurst DL, Appelo CAJ (1999) User's guide to PHREEQC (Version 2) - a computer program for speciation, batchreaction, one-dimensional transport, and inverse geochemical calculations. US Geological Survey WaterResources Investigations Report nr Report 99-4259

Picioreanu C, Head IM, Katuri KP, van Loosdrecht MCM, Scott K (2007) A computational model for biofilm-based microbial fuel cells. Water Res 41(13):2921-2940. doi: 10.1016/j.watres.2007.04.009

Siegrist H, Vogt D, Garcia-Heras J, Gujer W (2002) Mathematical model for meso and thermophilic anaerobic sewage sludge digestion. Environ Sci Technol 36:11131123. doi:10.1021/es010139p

Tait S, Clarke WP, Keller J, Batstone DJ (2009) Removal of sulfate from high-strength wastewater by crystallisation. Water Res 43(3):762-772. doi:10.1016/j.watres.2008. 11.008

Takacs I, Murthy S, Smith S, McGrath M (2006) Chemical phosphorus removal to extremely low levels: experience of two plants in the Washington, DC area. Water Sci Technol 53(12):21-28. doi:10.2166/wst.2006.402 